\title{
The Governance System of Industrial Policy in the Era of Grow th in Korea from the Perspective of State-Society Relations
}

\author{
Seok-Jin Eom* and Kwanpyo Bae**
}

\begin{abstract}
In this study, the authors examine the governance system of industrial policy in the era of economic growth in Korea from the perspective of statesociety relations. Specifically, we consider the public and private actors who engaged in governance processes related to industrial policy and their interactions, as well as the formal and informal institutions that constrained the actors. As a principal actor, the government established the effective and efficient institutions in each stage of the governance process. These institutions not only enhanced the industrial policy capacity of the government but also created an environment that permitted various stakeholders in private sector to be involved in the governance system. The private actors in the governance process, in turn, became major sources of information and driving forces of industrial promotion.
\end{abstract}

Keywords: governance, industrial policy, institutions, state-society relations, economic development in Korea

\section{INTRODUCTION}

It is well known that Korea has recorded rapid economic growth rates over the past five decades. Per capita GNP increased from less than US\$100 in 1960 to more than US\$ 20,000 in 2010. As Westphal (1990, p. 41), among many other development economists, noted, this growth was accompanied by industrial policies actively introduced by the government: "Korea's government has selectively intervened to affect the allocation of resources among industrial activities." The government selected industries that could have export competiveness at each development stage- the

\footnotetext{
* Seok-Jin Eom, corresponding author, is an associate professor in the Graduate School of Public Administration at Seoul National University. E-mail: sjum21@snu.ac.kr.

** Kwanpyo Bae is a doctoral candidate in the Graduate School of Public Administration at Seoul National University.
}

Manuscript received October 31, 2014; out for review November 10, 2014; review completed November 28, 2014; accepted December 1, 2014.

The Korean Journal of Policy Studies, Vol. 29, No. 3 (2014), pp. 1-30.

(C) 2014 by the GSPA, Seoul National University 
labor-intensive light industry in 1960s, the heavy and chemical industry in 1970s, and the information technology industry since the latter half of the 1980s.

There have been a number of studies that have sought to account for Korea's extraordinary success, which has led to a reasonably good understanding of the role that government institutions played in helping or impeding economic development. Korea's success has been explained by reference to both neoclassical institutional theory that emphasizes the role of institutions that might be considered as prior to and conditioning individual behavior and developmental state theory, a term used by international political economy scholars to refer to the phenomenon of state-led development in East Asia.

In spite of the contributions of previous research based on developmental state theory, we still do not have sufficient answers to following questions about the industrial promotion in Korea. How does the government build coalitions and align a diverse group of stakeholders consisting of government officials, businessmen, bureaucrats, academics, and so forth with its policies? How do government officials maintain their ties with influential members of the private sector? How has the government informally settled disputes that have arisen with within governmental organizations or between government officials and members of the private sector? What types of credible commitment mechanisms have governments employed to elicit the trust of the diverse stakeholders?

To fill in the gaps regarding the interactions between the government and private stakeholders and to enhance our understanding of the changes and continuities in industrial promotion in the era of economic growth in Korea, this study aims to analyze the governance systems of industrial policy, emphasizing the institutional arrangements and participation of various actors. More specifically, this study analyzes the governance systems from the perspective of state-society relations with exploring formal and informal institutions of the state, public and private actors in the institutions, and their interactions in the governance process.

The authors examined a wealth of archival data, including white papers, newspaper articles, academic papers, and testimonies, as well as policy reports published by executive agencies, the National Assembly, and research institutes analyzing them thematically in an effort to develop a systematic understanding of actors and the constraints that the institutional arrangements of the governance process for industrial promotion places on them. The remainder of this paper is organized as follows. The theoretical basis of this research is presented in section 2. The analysis of the governance system of industrial promotion and its characteristics are discussed in section 3. Finally, the implications for other developing countries are suggested as concluding remarks in section 4. 


\section{THE CONCEPTUAL FRAMEWORK OF GOVERNANCE}

\section{Governance from the Perspective of State and Society Relations}

Understanding governance is essentially a matter of understanding the nature of state-society relations in the pursuit of collective interests. It is clear that both the state and society participate in governance, although the degree of their involvement will not be uniform across nations or policy fields (Pierre \& Peters, 2005, p. 6). For example, the role of networks and other societal actors in governance still depends on their capacity to enforce decisions, necessarily implicating the power of the public sector and its legitimate authority. On the other hand, the use of the private sector is often a means through which the public sector is able to legitimate as well as enhance the efficiency and effectiveness of its actions (Bell \& Hindmoor, 2009, pp. 6-10).

What, then, is "governance"? From the perspective of state-society relations, governance refers to tools, strategies, procedures, and administrative processing mechanisms that determine how power is executed, how people's opinions are presented, and how decisions are made regarding matters of public interest (Pierre \& Peters, 2005, p. 2; Lynn et al., 2001, p. 7). It is generally believed that a state-society relations approach in research on governance is more relevant to the study of economic development and industrial policy than other approaches. This is because actors from both the state and society take part in developmental projects and interact through rational discussions, persuasion, and coordination of policy processes. Therefore, it has been argued that development programs based on a synthesis of state-, market-, and civil society-centered paradigms should be created to enhance the effectiveness of developmental programs in underdeveloped countries (Kwon, 2010; Evans, 1997).

\section{Building Blocks of Governance}

\section{Actors and Institutions}

An analysis of governance focuses on the formal and informal actors involved in governance. They participate in the decision-making and implementation processes at various levels. All actors involved in governance, regardless of whether they belong to the state or society, are interconnected and interact with other, negotiating and compromising, exchanging information and making political agreements, and leading and following. Government can be conceptualized as one of the participants in the governance system (Pierre \& Peters, 2005, pp. 13-14; Stoker, 1998; Rhodes, 1996).

However, these actors are constrained by formal and informal institutions. In fact, a 
government is commonly divided into numerous departments and various levels of administration, even though some research has treated the government as a unitary entity. Such divisions in the government can be an obstacle to the achievement of collective goals. Therefore, as a response to this problem, the government often establishes institutional standards within and across levels of the government (Timmermans, 2001; Weaver \& Rockman, 1993, pp. 10-11).

Just as the state is a differentiated actor, so too is society. In rural areas, for example, influential landlords, associations of peasant farmers, cooperatives, NGOs, and formal and informal leaders of villages all participate in governance. On the one hand, these social actors may have interests that compete with one another. On the other hand, they act under various social structures that specify how they may operate and the manner in which they may make decisions on their own or participate in collective decision making. Such social structures and mechanisms that promote decision making related to securing collective goals can affect the overall capacity of governance (Bell \& Hindmoor, 2009, p. 110; Pierre \& Peters, 2005, p. 13). Thus, we should pay attention to the social contexts within which they forge agreements regarding collective goals and the mechanisms through which they participate in decision-making processes.

\section{Process}

In the pursuit of serving public interests, the actors involved in governance carry out certain functions and interact with one another. From the viewpoint of governance process, these functions include goal-selection, decision-making, resource-mobilization, instruments and implementation, and provision of feedback (Pierre \& Peters, 2005, pp. 14-16). First, "goal-selection" involves identifying the collective goals of society, and "decision-making" involves determining how to attain the goals that have been established. Both are extremely crucial and constitute the first part of the governance process. Second, "resource-mobilization" refers to the need to identify and mobilize public and private resources that can be used to reach the goals. Among these are financial as well as personnel and legitimacy resources. Third, "instruments and implementation" is the stage at which the goals and the intended effects are realized. For these functions to be carried out successfully, effective instruments and strategies should be adopted. Fourth, "provision of feedback" consists of a series of actions including evaluating instruments used in the past and feeding the information from that evaluation back into the decision-making process. In this way, the governance system is continually adjusted by means of information exchanges and political agreements. 


\section{Outcomes}

Whereas the principal concern of the government is the formation of policy, the primary concern of governance is the outcomes of the process. A specific policy or program yields results in the form of outcomes that can be quantified, for example, as economic growth rate, crime rate, or educational standards (Bell \& Hindmoor, 2009, p. 110). Additionally, some scholars consider broader characteristics of the policies adopted or more comprehensive sets of outcomes as outcomes of governance. For example, Pierre and Peters (2005, pp. 16-17) present the overall characteristics of governance, including coherence, inclusiveness, adaptability, and accountability, as outcomes of governance. Following this viewpoint, the characteristics of good governance can be formulated as outcomes such as participation, transparency, responsiveness, consensus orientation, effectiveness, and efficiency (UNESCAP, 2007; ODI, 2006).

\section{Models of Governance}

From the perspective of state-society relations, there are five fundamental models of governance that developed and developing countries have adopted (Pierre \& Peters, 2005, pp. 11-12). First is the étatiste model. In this model, the principal actor for all aspects of governance is a government that possesses the capacity to govern and control the manner in which social actors are permitted to participate in the governing process, if they are at all. Second is the liberal-democratic model. Here the state is the principal actor in governance, and other actors compete with other each in an effort to influence the state. The state has the opportunity to pick and choose the interest groups or other social actors that it will permit to have influence. Third is the state-centric model. In this model, the state remains at the center of the process but institutionalizes its relationship with social actors. The state has substantial power to accept or reject partners but is more bound to its partners. One example of this model is corporatism. Fourth is the Dutch governance school model, which has mainly been developed by Dutch scholars drawing on the circumstances of Dutch politics. This model is heavily dependent on the role of social networks in governing, with the state being merely one among many actors. In this model, society is the more powerful actor, given its capacity to organize itself to evade the power of the state and its attempts at regulation. Fifth is the governance without government model. In this model, the state has lost its capacity to govern and has become an arena in which private interests create more or less selfsteering governance arrangements that satisfy their own needs and desires. The 
concrete characteristics of the models in terms of the building blocks of governance are summarized in table 1.

Table 1. Characteristics of Governance Models

\begin{tabular}{|c|c|c|c|}
\hline Governance Models & Actors & Process & Outcomes \\
\hline & & $\begin{array}{l}\text { - goal selection } \\
\text { - decision making } \\
\text { - resource mobilization } \\
\text { - implementation } \\
\text { - feedback }\end{array}$ & $\begin{array}{l}\text { - cohesiveness } \\
\text { - inclusiveness } \\
\text { - adaptability } \\
\text { - accountability }\end{array}$ \\
\hline étatiste model & $\begin{array}{l}\text { state as a } \\
\text { principal actor } \\
\text { for all aspects } \\
\text { of governance }\end{array}$ & $\begin{array}{l}\text { - goal selection is state } \\
\text { dominated } \\
\text { - decision making is } \\
\text { technocratic } \\
\text { - resources are mobilized } \\
\text { by the state, which serves } \\
\text { as both entrepreneur and } \\
\text { taxman } \\
\text { - implementation is } \\
\text { accomplished via coercive } \\
\text { instruments } \\
\text { - the state tends to be little } \\
\text { concerned with role and } \\
\text { utility of feedback from } \\
\text { society }\end{array}$ & $\begin{array}{l}\text { - not highly cohesive, as } \\
\text { turf wars within the state } \\
\text { are typical } \\
\text { - not inclusive, but the } \\
\text { state does strategically } \\
\text { allow certain segments } \\
\text { of society to have an } \\
\text { influence } \\
\text { - adaptability is limited } \\
\text { - accountability is } \\
\text { accomplished internally }\end{array}$ \\
\hline $\begin{array}{l}\text { liberal-democratic } \\
\text { model }\end{array}$ & \begin{tabular}{|l|} 
- state \\
organizations \\
or institutions \\
- societal \\
interests
\end{tabular} & $\begin{array}{l}\text { - goal selection is a more } \\
\text { competitive process than } \\
\text { with the étatiste model } \\
\text { and bureaucratic politics } \\
\text { - decision making is a } \\
\text { symbiotic process between } \\
\text { state and social interests } \\
\text { - beneficiaries of policies } \\
\text { are burdened with } \\
\text { mobilizing resources } \\
\text { - implementation is the } \\
\text { least coercive of the five } \\
\text { models; it is carried out } \\
\text { by third-parties and is } \\
\text { self-regulatory } \\
\text { - feedback is incomplete } \\
\text { and biased }\end{array}$ & $\begin{array}{l}\text { - there is a trade-off } \\
\text { between cohesiveness } \\
\text { and the desire to secure } \\
\text { political consent } \\
\text { - oligopolistic } \\
\text { - adaptability is limited by } \\
\text { the absence of any } \\
\text { consensus about form } \\
\text { adaptation should take } \\
\text { - multiple channels of } \\
\text { accountability }\end{array}$ \\
\hline
\end{tabular}




\begin{tabular}{|c|c|c|c|}
\hline Governance Models & Actors & Process & Outcomes \\
\hline state-centric model & $\begin{array}{l}\text { state and } \\
\text { peak societal } \\
\text { organizations }\end{array}$ & $\begin{array}{l}\text { - state plays a primary role } \\
\text { in goal selection } \\
\text { - diverse forms of decision } \\
\text { making are adopted in } \\
\text { accordance with the various } \\
\text { types of corporatism } \\
\text { - resource mobilization is } \\
\text { distributive } \\
\text { - implementation is } \\
\text { interactive and negotiated } \\
\text { between state and society } \\
\text { - feedback is better than in } \\
\text { other models but still } \\
\text { biased }\end{array}$ & $\begin{array}{l}\text { - high level of coherence } \\
\text { - can be very inclusive but } \\
\text { is selective and indirect } \\
\text { at other times } \\
\text { - better at distributing } \\
\text { gains but worse at } \\
\text { distributing losses } \\
\text { - actors who should be } \\
\text { held accountable are not } \\
\text { the actors who in fact } \\
\text { are }\end{array}$ \\
\hline $\begin{array}{l}\text { Dutch governance } \\
\text { school model }\end{array}$ & $\begin{array}{l}\text { networks of } \\
\text { diverse and } \\
\text { socially } \\
\text { significant } \\
\text { actors }\end{array}$ & $\begin{array}{l}\text { - goal selection is the state's } \\
\text { primary responsibility } \\
\text { - decision-making processes } \\
\text { are not very formalized } \\
\text { - both state and society } \\
\text { have a strong capacity for } \\
\text { mobilizing resources } \\
\text { - implementation is } \\
\text { cooperative and self- } \\
\text { regulating } \\
\text { - feedback is not as } \\
\text { efficacious as typically } \\
\text { assumed }\end{array}$ & $\begin{array}{l}\text { - problematic because of } \\
\text { heterogeneity and } \\
\text { diversity of the actors } \\
\text { - high degree of } \\
\text { inclusiveness } \\
\text { - high level of adaptability } \\
\text { by ad-hoc, matrix-type } \\
\text { task forces } \\
\text { - driven to an increasing } \\
\text { extent by performance } \\
\text { management and other } \\
\text { institutionalized means }\end{array}$ \\
\hline $\begin{array}{l}\text { governance without } \\
\text { government model }\end{array}$ & $\begin{array}{l}\text { interorganizational, } \\
\text { self-governing } \\
\text { networks and } \\
\text { key participants } \\
\text { in these } \\
\text { networks }\end{array}$ & $\begin{array}{l}\text { - goal selection is } \\
\text { determined more by what } \\
\text { is in the interests of the } \\
\text { network participants than } \\
\text { by the state } \\
\text { - decision making is } \\
\text { consensual } \\
\text { - resources are mobilized } \\
\text { from the state } \\
\text { - effective in implementing } \\
\text { the network participants' } \\
\text { goals but obstructive to } \\
\text { government policy } \\
\text { - feedback is likely to be } \\
\text { biased in favor of the } \\
\text { interests of the network }\end{array}$ & $\begin{array}{l}\text { - cohesive within the } \\
\text { network but not across } \\
\text { sectors } \\
\text { - not inclusive because of } \\
\text { limitations of access to } \\
\text { the network } \\
\text { - adaptability at the level } \\
\text { of state can be impaired } \\
\text { by networks } \\
\text { - confused and limited }\end{array}$ \\
\hline
\end{tabular}

Source: Adapted from Pierre \& Peters 2005, pp. 17-45. 
In the following section, we first examine the governance process of industrial policy during the heyday of Korea's economic growth in terms of the broad features outlined by Pierre \& Peters (2005) model of governance and consider the major tasks and functions of each stage of the process. Second, we examine the institutional arrangements that were made for satisfying each stage of the governance process and for promoting and constraining the actors who participated in the formulation and implementation of industrial policy. Third, we identify the major actors and analyze their interactions in each stage of the governance process.

\section{ANALYSIS: THE GOVERNANCE SYSTEM OF INDUSTRIAL PROMOTION}

\section{Goal Selection}

In 1961, General Park Chung-hee staged a coup. The military junta declared that economic development would be the top priority. He was aware that a self-sustaining economy was needed to realize a "true liberal democracy" (C. Park, 1962). On July 22, 1961, the military junta established the Economic Planning Board (EPB) and on July 31, it announced the comprehensive economic reconstruction plan. This plan was developed by the civilian advisors to the Economic Reconstruction Planning Committee, based on the plans of the previous government and strategized on ways to improve the international balance of payments and to achieve a high growth rate by mobilizing national resources.

This framework was maintained until the fourth five-year plan, even though the tools, resources, and objects of industrial policy changed in accordance with the evolution of the industrial structure. For example, one of the second plan's "basic goals" was "to promote establishment of a self-sustaining economy" (EPB, 1966), and one of the third plan's "basic plans" was "to establish a self-sustaining economy" (EPB, 1971), while one of the fourth plan's "basic goals" was "to establish a self-sustaining growth structure" (EPB, 1976).

\section{Institutions}

The EPB in charge of the plan adopted the functions of budget compilation and statistics from the Ministry of Finance and the Ministry of Home Affairs and introduced the functions of technical management and foreign capital management. In 1964, the EPB was authorized to head up economic policy making, after the minister of the EPB 
was given the position of deputy prime minister.

The plans were drafted from the subplans of practical planning groups. The EPB supplied guidelines, and the ministry that was responsible for implementing each plan led the group. Its bureaucrat became the head of the group, while an official of the EPB took on the role of the coordinator. The group itself was made up of bureaucrats from relevant ministries, professors, experts of public or private organizations and so forth. The group provided a kind of forum for designing feasible goals.

Additionally, the EPB drew up a yearly plan to implement the long-range plan. The yearly plan specified a target growth rate, GNP, inflation rate, amounts of imports and exports, and so forth. The various ministries that had their particular constituencies and points of view collaborated to set the numerical target of these macro indexes. For example, the EPB negotiated the wage increase rate with the Ministry of Labor, the currency rate with the Ministry of Finance, and export target figures with the Ministry of Commerce and Industry (MCI).

\section{Roles of Actors}

The first plan, which was formulated in the absence of necessary information, institutions and collaborations, was just a list of construction plans for major factories (interview with former Vice Minister Gyung-shik Lee, cited in Kang et al., 2008, p. 291). Even though the second plan was drawn up by seven practical planning groups and benefited from the advice of U.S. specialists, such as the Nathan Advisory Group and Edward Shaw (Cole \& Nam, 1969, pp. 13-14; Kang et al, 2008, p. 329), the plan-making process was not systematic. The process depended on one individual, Hak-ryul Kim, who was the vice minister of the EPB. The plan-making process became better organized when the EPB prepared the third plan with input from bureaucrats, professors, and experts.

There were a total of 22 practical planning groups for the fourth plan: four for the divisional plan of the EPB and the rest for the divisional plans of the MCI, the Ministry of Finance, the Ministry of Construction, the Economic Science Council, the Ministry of Agriculture-Forestry-Fisheries, the Ministry of Home Affairs, and the Korean Development Institute, among others. A bureaucrat of the ministry in charge of the divisional plan led the group, and an official of the EPB was the coordinator as shown in table 2. About half of the members were bureaucrats from the MCI, the Ministry of Finance, and the Ministry of Construction rather than members of the EPB. Experts from public institutions like the Bank of Korea and Research Institute of Science and Technology accounted for $33.2 \%$. The percentage of civilians, who were mostly professors and experts from industrial associations, was $15.7 \%$. 
Table 2. Composition of the Practical Planning Groups (Plan 4)

\begin{tabular}{l|c|c|l}
\hline \multicolumn{1}{c|}{ Category } & No. of Members & Percentage & \multicolumn{1}{c}{ Notes } \\
\hline government & 146 & $51.0 \%$ & $\begin{array}{l}\mathrm{MCl}(20), \text { Ministry of Finance (16), } \\
\text { Ministry of Construction (13), EPB (10), etc. }\end{array}$ \\
\hline public institutions & 95 & $33.2 \%$ & $\begin{array}{l}\text { Korean Development Institute (29), } \\
\text { Bank of Korea (14), Research Institute of } \\
\text { Science and Technology (13), etc. }\end{array}$ \\
\hline civilians & 45 & $15.7 \%$ & $\begin{array}{l}\text { universities (28), corporations / } \\
\text { associations (17) }\end{array}$ \\
\hline
\end{tabular}

Source: EPB 1975.

For example, the MCI in charge of the heavy-chemical-industry plan managed a practical planning group that many civilian experts participated in, as shown in table 3 . The assistant vice minister of heavy industry from the MCI led the group, and a bureaucrat from the Investment Department of the EPB was the coordinator. Other members included bureaucrats from relevant ministries and civilian experts.

Table 3. Practical Planning Group for Heavy Industry (Plan 4)

\begin{tabular}{|c|c|c|c|}
\hline $\begin{array}{l}\text { Supervisory } \\
\text { Ministry }\end{array}$ & Head & Coordinator & Members (21) \\
\hline $\mathrm{MCl}$ & $\begin{array}{c}\mathrm{MCl} \\
\text { (assistant vice } \\
\text { minister of } \\
\text { heavy industry) }\end{array}$ & $\begin{array}{c}\text { EPB } \\
\text { (Investment } \\
\text { Department) }\end{array}$ & $\begin{array}{l}\mathrm{MCI} \text { (directors for industrial planning, heavy } \\
\text { industry, mechanical industry, and chemical } \\
\text { industry), Ministry of Finance (director for financial } \\
\text { systems and section chief for tariff systems), } \\
\text { Ministry of Construction (director of industrial } \\
\text { sites), the Office of Science and Technology } \\
\text { (director of human resources planning), the heavy } \\
\text { and chemical planning group (senior officer for } \\
\text { planning), researchers from the Korean } \\
\text { Development Institute and the Korea Institute of } \\
\text { Science and Technology (2), and experts from } \\
\text { the Industrial Bank, the Federation of Korean } \\
\text { Industries, the Korea Chamber of Commerce and } \\
\text { Industry, the Korea Association of Machinery } \\
\text { Industry, the Precision Instrument Center, the } \\
\text { Korea Maritime Research Institute, and the Korea } \\
\text { Industrial Development Institute }\end{array}$ \\
\hline
\end{tabular}

Source: EPB 1975.

There were many civilian participants, along with bureaucrats from relative ministries, who together constituted a kind of forum of equal members that cooperatively formulated goals, elaborating common interests by respecting each other's interests. 
The government listened to the voices of businesspeople and sought to establish policies that would provide the highest benefits for them (Sagong \& Johnson, 1981, pp. 9899). ${ }^{1}$ In addition, the goals of the government and the benefits to businesses were synchronized during the process of drawing up the plan (S. Choi, 2008). In other words, the process of elaborating goals for industrial promotion was a process of adjustment between the mutual interests of the government and businesses. ${ }^{2}$

\section{Decision Making}

Although the first plan was imperative, it had limitations due to the lack of resources, and the plan was eventually revised in 1964. This experience caused the subsequent plans to become indicative gradually since the second plan. The second plan set macroscopic goals, and the microscopic decisions for achieving these goals were decided in multiple levels of meetings that President Park or high-ranking bureaucrats presided over. Table 4 shows the agendas of the monthly enlarged meeting

Table 4. Agendas of the Enlarged Meeting for the Exported Promotion (1966-1980)

\begin{tabular}{l|c}
\hline \multicolumn{1}{c|}{ Agendas } & Total Number of Agendas \\
\hline 1. export promotion policies & 96 \\
2. strategies for export items & 48 \\
3. overseas market information and market exploitation updates & 37 \\
4. specific export strategies & 28 \\
5. setting and adjusting target number of items to be exported & 18 \\
6. reports on saemaeul (new village movement) factories & 13 \\
7. improvement of export goods & 8 \\
8. results of trade talks with foreign countries & 6 \\
\hline
\end{tabular}

Source: D. Choi 1991, p. 108.

1. Regarding the relationship between government and business, a businessman at the time offered following testimony: "Bureaucrats and businessmen were very similar in age, thought, sense of duty, etc. We shared a willingness to negotiate to achieve our goals. . . . So, the relationship should not be considered as collusive or corrupt one. . . . I believe there were common interests in sharing and pursuing goals in the 1960s" (interview with H company former employee, Mr. K, September 1996, cited in Ha, 2006, 147).

2. Testimony offered by Kang Gyung-shik describes the process as follows: "I believe the five-year plans were 'flags.' In other words, making the plans was a symbolic action that showed the willingness of the president to put the economy at the top of the list. . . In this regard, the planning process was greatly important. The planning process was an agreement-making process that set economic development as the top priority (Kang Gyung-shik, cited in Kang et al., 2008, 78-79). 
for export promotion, which was a distinguished monthly meeting presided over by the president. The core decisions for export-oriented industrialization were made during the enlarged meeting. These decisions were formalized in acts, measures, or industrial plans.

\section{Institutions}

Decision making took place in multiple organizations. Decisions were made in a meeting of vice ministers, which was held in preparation of cabinet meetings. Because the cabinet meeting was the last step in the decision-making process in the executive branch, decisions about what items the cabinet should deliberate on were often made in advance, at the vice ministers' meeting (J. Jung, 1994, p. 45).

Decisions were also made at meetings of the economic ministers and the economic ministers' talk. The economic ministers began holding formal twice-weekly meetings in 1964 (J. Jung, 1994, p. 51; D. Choi, 1991, pp. 63-64). The EPB adjudicated the decision-making process. For instance, a proposal that an official of the EPB received from another ministry would be circulated among the officials of the EPB. If there were differences of opinion among them, the differences would be addressed before the proposal was put on the agenda (D. Choi, 1991, pp. 63-64). The economic ministers' talk was less regulated than the meeting of the economic ministers by the bureaucratic hierarchy. Its agendas, the date of its meetings, and even its members were not fixed. If an important agenda item came up, the secretary to the president for economic policy could join in. The way that the talk was set enabled quick and flexible decision making (D. Choi, 1991, pp. 66-67).

Two major economic ministries, the EPB and the MCI, likewise conducted a monthly meeting that the president presided over. The monthly economic issues briefing meeting was hosted by the EPB, and the president always participated in them. The president was briefed on economic issues and then posed questions. In the meeting, the various participants shared information about the status of the issues, the measures that might be taken to address the issues and the obstacles in the way of resolving them, and bench-marking cases that might be referred in the course of carrying out the programs. The meetings became an institutional framework, with the EPB leading economic policies. At the same time, the MCI provided another institutional framework. It hosted the monthly enlarged meeting for export promotion, which was also presided over by the president. It was held almost every month after 1965, and President Park attended most of them (S. Choi, 2010b). At these meetings, the results of previous meetings and progress of the ongoing plans were reported and analyzed, and solutions for removing obstacles that were hindering exports were discussed. 
Some decisions were made in the president's secretary office. Jung-ryum Kim, the chief secretary in the Park administration, strengthened the capabilities of the office by expanding economic organizations in the Blue House. For example, in 1971, another senior secretary office was established to manage particular economic affairs such as the defense industry and heavy and chemical industrialization. The assistant vice minister of the MCI, Won-chul Oh, who proposed the policy change from light industry to heavy and chemical industry, was appointed as the senior secretary of this new office, and five elite bureaucrats of the MCI were recruited. The office occasionally regulated relevant ministries by organizing and managing temporary bodies. For example, the heavy and chemical industry promotion planning group was a temporary group that led the development of the industry. The secretary Oh was also the director of this planning group, and the deputy director was a high-ranking secretary of the Blue House. Other members were from relevant ministries (D. Choi, 1991, pp. 98-99). The distance between the president and ministries became gradually larger, as the presidential secretaries assumed a growing presence in the government, as shown in table 5.

Table 5. President Park's Face-to-face Talks (\%)

\begin{tabular}{l|c|c|c|c}
\hline & $1964-1966$ & $1967-1971$ & $1972-1976$ & $1977-1979$ \\
\hline with bureaucrats of EPB & $5.5 \%$ & $4.7 \%$ & $2.1 \%$ & $1.6 \%$ \\
\hline with bureaucrats of $\mathrm{MCl}$ & $1.8 \%$ & $2.0 \%$ & $1.9 \%$ & $1.4 \%$ \\
\hline with presidential secretaries & $1.9 \%$ & $14.3 \%$ & $18.7 \%$ & $48.2 \%$ \\
\hline
\end{tabular}

Source: H. Kim 2009.

\section{Roles of Actors}

Various kinds of actors could be engaged in making various decisions via these multiple decision-making institutions. President Park made decisions especially at the economic issues briefing meeting and the monthly enlarged meeting for export promotion. Various actors such as not only bureaucrats, politicians, and experts of public institutions, but also businessmen and journalists were invited to these meetings (D. Choi, 1991, pp. 67-73). ${ }^{3}$

3. The journalists served as communicators with the public. Regarding the importance of the president's presence and the roles of journalists for industrial policy, a former minister at the time remarked that "if the president did not preside over the monthly economic issues briefing meeting, how was the news about the meeting to be widely disseminated? The 
For example, 98 individuals were invited to the third meeting held in 1967: the president, 18 ministers (including vice ministers), 17 directors and section-chiefs, six heads of public institutions, eight experts of the business organizations or public enterprises, three professors, four executives from the legislative or judicial branch, 12 private enterprise businessmen, and 29 regional representatives (11 bureaucrats, ten heads or directors of the local government, and eight professors and one banker). Furthermore, the monthly enlarged meeting for export promotion was reorganized and expanded to the enlarged meeting for trade promotion in 1977, and about 200 individuals participated in that meeting (S. Jang, 2006, pp. 75-76).

Due to the openness of the monthly enlarged meeting for export promotion, the actors in the field had an opportunity to advance their opinions. For example, the institutionalization of the general trading company was proposed by mission chiefs to Southeast Asia in the fourth monthly enlarged meeting for export promotion of 1969, and they proposed it again in the second meeting of 1973, and the tenth meeting of 1974. It was institutionalized through discussion in the twelfth meeting of 1974, and the fourth and fifth of 1975. Tax reductions, financial supports, funding supports, and so forth were settled on in the following meetings (Lee, 2012; S. Jang, 2006, pp. 78-80).

Actors also sometimes competed in these decision-making forums. Ministers, directors, and even section chiefs, who were in charge of making the briefing charts, attended the briefing session and answered the president's questions. If two ministries had different opinions on an issue, representatives of both presented briefings in the president's presence. Representatives had vigorous debates, and the president made the final decision after hearing both sides (Oh, 2006, pp. 11, 15). For instance, the MCI objected to the EPB's desire to fund the construction of the fertilizer plant by inviting foreign capital. The two ministries clashed over the contract conditions of the new fertilizer plant operation. After hearing both sides' briefings, President Park accepted the EPB's request to guarantee more loans, which the country needed desperately at the time (Oh, 1995, pp. 171-177).

audience for it would be very small. But because the president presided over the meeting, the press published many articles on it. The agenda of the presidential meeting became the first priority; that is, the ministries were expected to concentrate their attention on the agenda and to allocate resources for accomplishing it" (Suk-je Lee, cited in Kang et al., 2008, 137, 177). 


\section{Resource Mobilization}

The government mobilized the material and the human resources of the state and society to implement industrial policies. The government, especially in the 1960s, had a great interest in mobilizing resources because in the wake of the Korean War and the Japanese colonial era, Korea found itself without a structure of capital accumulation (J. Kim, 2004). The government urged bureaucrats to push the work and stressed the citizens' spirit of self-help and diligence. The government tried to turn negative capital into positive capital, acquire more foreign loans, and invite more foreign investments. The rate of savings was so poor that the government was forced to depend on foreign capital, as shown in table 6 .

Table 6. Korea's Rate of Dependence Rate on Foreign Capital and the Amount of Foreign Capital per Planning Period, 1962-1986

\begin{tabular}{|c|c|c|c|c|c|c|}
\hline & $\begin{array}{c}\text { First Plan } \\
(1962-1966)\end{array}$ & $\begin{array}{l}\text { Second Plan } \\
(1967-1971)\end{array}$ & $\begin{array}{l}\text { Third Plan } \\
(1972-1976)\end{array}$ & \begin{tabular}{|c|} 
Fourth Plan \\
$(1977-1981)$
\end{tabular} & $\begin{array}{c}\text { Fifth Plan } \\
(1982-1986)\end{array}$ & Total \\
\hline $\begin{array}{l}\text { total Investment ratio* } \\
(\%)\end{array}$ & $\begin{array}{l}15.1 \\
(100)\end{array}$ & $\begin{array}{l}25.7 \\
(100)\end{array}$ & $\begin{array}{l}27.8 \\
(100)\end{array}$ & $\begin{array}{l}26.5 \\
(100)\end{array}$ & $\begin{array}{l}28.8 \\
(100)\end{array}$ & \\
\hline $\begin{array}{l}\text { domestic rate of } \\
\text { savings }(\%)\end{array}$ & $\begin{array}{c}6.1 \\
(40.4)\end{array}$ & $\begin{array}{l}15.7 \\
(61.1)\end{array}$ & $\begin{array}{c}18.0 \\
(64.7)\end{array}$ & $\begin{array}{l}25.9 \\
(97.7)\end{array}$ & $\begin{array}{l}28.7 \\
(99.7)\end{array}$ & \\
\hline $\begin{array}{l}\text { overseas rate of } \\
\text { savings (\%) }\end{array}$ & $\begin{array}{c}9.0 \\
(59.6)\end{array}$ & $\begin{array}{l}10.0 \\
(38.9)\end{array}$ & $\begin{array}{c}9.8 \\
(35.3)\end{array}$ & $\begin{array}{c}0.6 \\
(2.3)\end{array}$ & $\begin{array}{c}0.1 \\
(0.3)\end{array}$ & \\
\hline $\begin{array}{l}\text { amount of foreign } \\
\text { capital sought }{ }^{\star \star}\end{array}$ & 684 & 1,052 & 3,869 & 13,322 & 37,485 & 56,412 \\
\hline $\begin{array}{l}\text { amount of foreign } \\
\text { capital received }^{* \star \star}\end{array}$ & 313 & 2,445 & 6,595 & 18,485 & 25,764 & 53,602 \\
\hline public loans (\%) & $\begin{array}{c}116 \\
(37.1)\end{array}$ & $\begin{array}{c}811 \\
(33.2)\end{array}$ & $\begin{array}{l}2,416 \\
(36.6)\end{array}$ & $\begin{array}{l}5,751 \\
(31.1)\end{array}$ & $\begin{array}{l}6,691 \\
(26.0)\end{array}$ & $\begin{array}{c}15,785 \\
(29.4)\end{array}$ \\
\hline $\begin{array}{l}\text { commercial loans } \\
(\%)\end{array}$ & $\begin{array}{c}176 \\
(56.2)\end{array}$ & $\begin{array}{l}1,538 \\
(62.9)\end{array}$ & $\begin{array}{l}3,622 \\
(54.9)\end{array}$ & $\begin{array}{c}12,202 \\
(66.0)\end{array}$ & $\begin{array}{c}17,973 \\
(69.8)\end{array}$ & $\begin{array}{c}35.511 \\
(66.2)\end{array}$ \\
\hline $\begin{array}{l}\text { foreign investments } \\
(\%)\end{array}$ & $\begin{array}{l}21 \\
(6.7)\end{array}$ & $\begin{array}{c}96 \\
(3.9)\end{array}$ & $\begin{array}{l}557 \\
(8.4)\end{array}$ & $\begin{array}{l}532 \\
(2.9)\end{array}$ & $\begin{array}{l}1,100 \\
(4.3)\end{array}$ & $\begin{array}{c}2,306 \\
(4.3)\end{array}$ \\
\hline $\begin{array}{l}\text { amount received/ } \\
\text { amount sought }\end{array}$ & 45 & 232 & 170 & 139 & 69 & 95 \\
\hline
\end{tabular}

\footnotetext{
* Total investment ratio and rate of savings represent the average for the period of the plans (EPB, 1991).

** The amount of foreign capital sought was specified in the plans.

${ }^{* * *}$ The figure used here for amount of foreign capital received is the arrival price.

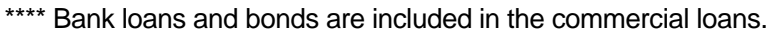

Source: D. Choi 1991, p. 116.
} 


\section{Institutions}

In the 1960s, institutions for resource mobilization began to be systemized. First, organizations were created and aligned to improve mobilization capabilities. Within the $\mathrm{EPB}$, a section for public loans and a section for private loans under the International Cooperation Bureau were established, as were a section for materials mobilization planning and for fiscal and monetary affairs under the Budget Bureau. The EPB also improved the mobilization capabilities of human resources by introducing a section for technology promotion under the Technology Management Bureau. In addition, the government established the National Tax Service in 1966 to collect more taxes.

These organizations executed measures to mobilize foreign capital. When foreign aid began to rapidly decrease in the early 1960s as shown in figure 1, President Park ordered to create institutions to acquire more foreign capital in order to promote industries (S. Choi, 2010a). The government reformed the Foreign Capital Introduction Act in 1961 to modify the permissible range of foreign investments. In 1962, the Guarantee Payment Act for Credit was enacted. The government guaranteed payments of principal and interest for those businesses that were needed to realize the plans. Also, trademark rights and patents of foreign businesses were to be strictly guarded (D. Choi, 1991, pp. 112-114). The act helped create a welcome environment for foreign investors.

Figure 1. Revenue Composition, 1948-1972

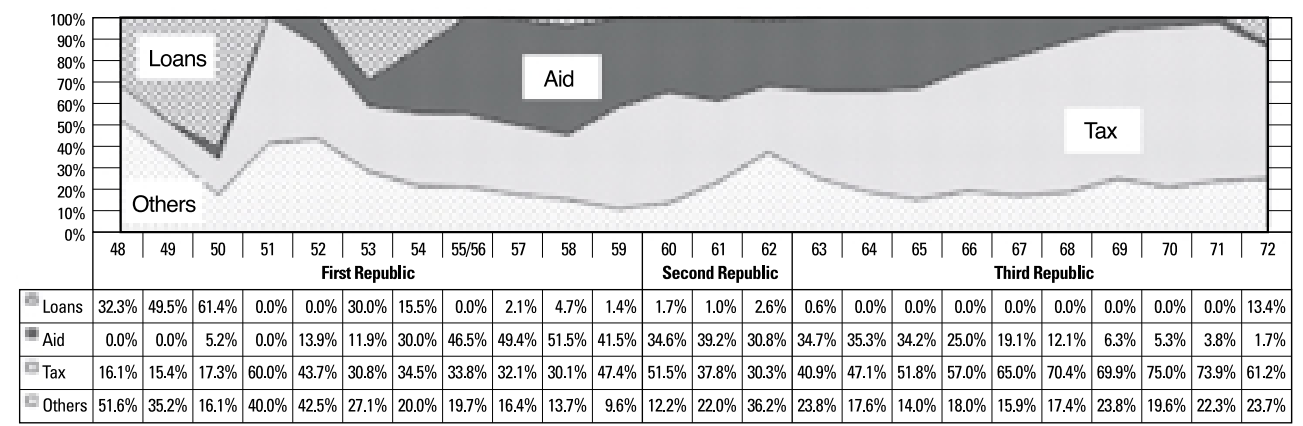

Source: 2010 budget summary.

The government itself likewise executed measures to mobilize domestic capital. For example, the government carried out financial reforms that increased the interest rates of fixed deposits from $15 \%$ to $30 \%$ in 1965 . The result of that measure was that total deposits from 1965 to 1969 increased 700\%. The financial reform of 1965 is often regarded as an instance of best practices according to neoclassical economic 
theory. It has been used as evidence that economic growth in Korea was based on the restoration of market functions. However, in reality, it expanded the scale of domestic capital that was under the control of the government by bringing out capital from the underground loan market (H. Jang, 1999).

The government also modified institutions so as to mobilize human resources. First, the government aligned the bureaucracy by revising the National Public Service Act in 1963. It adopted a position classification system, strengthened the open competitive examinations system, and guaranteed the status of public officials (D. Choi, 1991, pp. 124-131). In addition, the government increased the salary of public officials by $30 \%$ in $1966,23 \%$ in $1967,30 \%$ in $1968,30 \%$ in 1969 , and $20 \%$ in 1970 over the previous year (S. Lee, 1995, p. 232). Furthermore, the pension fund for public officials was also increased. The total number of public officials, consequently, began to rise, as shown in figure 2.

Figure 2. Number of Public Officials, 1953-1972

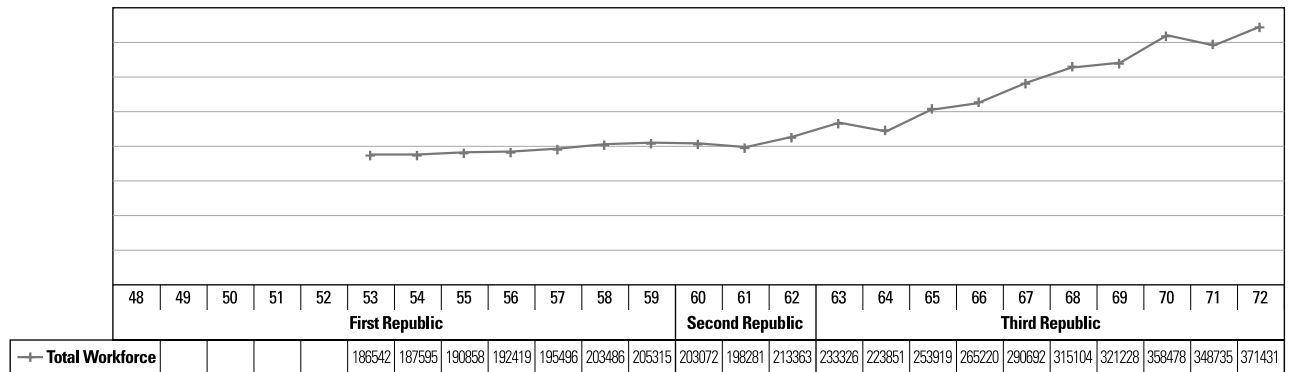

Source: Bae and Eom 2012.

Professionals in various fields were also mobilized. Immediately after the coup, civilian experts were hired from the government-run banks, and various technical experts were recruited. For example, the three directors of the MCI were chosen from among civilian experts with technical backgrounds and technicians, such as Won-chul Oh, who was hired as section chief. Meanwhile, the government began developing a long-term plan for human resources mobilization. The EPB announced the first science and technology policies in 1962 and began systematically training technicians (Y. Kim et al., 2010), establishing the Korea Institute of Science and Technology in 1966 and the Korean Development Institute in 1971. Furthermore, about 100 technical high schools, such as Kumoh Technical High School, were established. The graduates of these schools usually became good workers in the heavy and chemical industries. 


\section{Roles of Actors}

The military junta had tried to mobilize domestic capital by immediately executing the Urgent Currency Reform Act. However, it failed and made foreign businessmen and investors distrustful of the government at the initial stage of economic development. In the wake of the implementation of measures designed to systematically train Koreans, however, foreign private loans started flowing in. In 1964, private loans amounted to only $\$ 13$ million, but by 1969 , they had increased to $\$ 411$ million (Oh, 1996, p. 280). The government distributed foreign private loans that bore a low interest rate to the businessmen who planned to develop businesses that would help realize of the economic plan. Businessmen learned that they could earn more money if their business was selected by the Foreign Capital Introduction Council to be financed by foreign capital. All businessmen sought to receive this financing even when they did not have a detailed or concrete business plan. Eventually, the number of insolvent enterprises increased. The regulatory provisions of the Foreign Capital Introduction Act were strengthened in 1967 (D. Choi, 1991, pp. 115-116), and measures to restructure insolvent enterprises were introduced in 1969. The Blue House took a lead role by establishing an office under its administration specifically for handling the restructuring of insolvent enterprises.

Meanwhile, businessmen who needed large-scale foreign capital went oversea to get loans directly. For example, the CEO of Hyundai, Joo-young Jung, made every effort to acquire loans to start a shipbuilding business, which was a core business of the second plan of 1971. He negotiated with foreign investors and successfully arranged the investment. At that time the government just backed his activities. Previously, the state had built factories with foreign capital that was acquired diplomatically and then transferred ownership of the factories to selected businessmen. In 1970s, the businessmen started working independently with the support of the government. This shows that the social sector was growing.

\section{Instruments and Implementation}

"The value of an economic plan cannot be found in the plan itself. Rather its value depends on how much it can contribute to the economic growth of the state by its realization. If a poor plan contributes to rapid economic growth by being realized effectively, it is better than a good plan that has little possibility of being realized (EPB, 1967, p. 122)."

As this excerpt from a document of the EPB suggests, the government was fully 
aware that policies had to be effectively implemented if it was to achieve its goals. Drawing on the resources it had mobilized, the government sought to implement the policies that had been made and revised in the multiple meetings. Industrial structure policy was an attempt to enhance industrial structures. A representative example was heavy and chemical industrialization. Specific industrial policies were intended to revive stagnating industries or to foster strategic industries. Policies related to roads, harbors, communication, electricity, housing, sanitation, environment, and labor were included in industry-based policies. A combination of policies and mixed tools were used to expand exports in the 1960s, and another combination and tools were used to foster specific industries in the 1970s.

\section{Institutions}

Nonmonetary incentive tools and monetary incentive tools were embedded in institutions for industrial promotion. For example, in order to promote heavy and chemical industrialization, monetary tools and nonmonetary tools were mixed together, as shown in table 7.

Table 7. Factors in the Promotion of the Industry Act

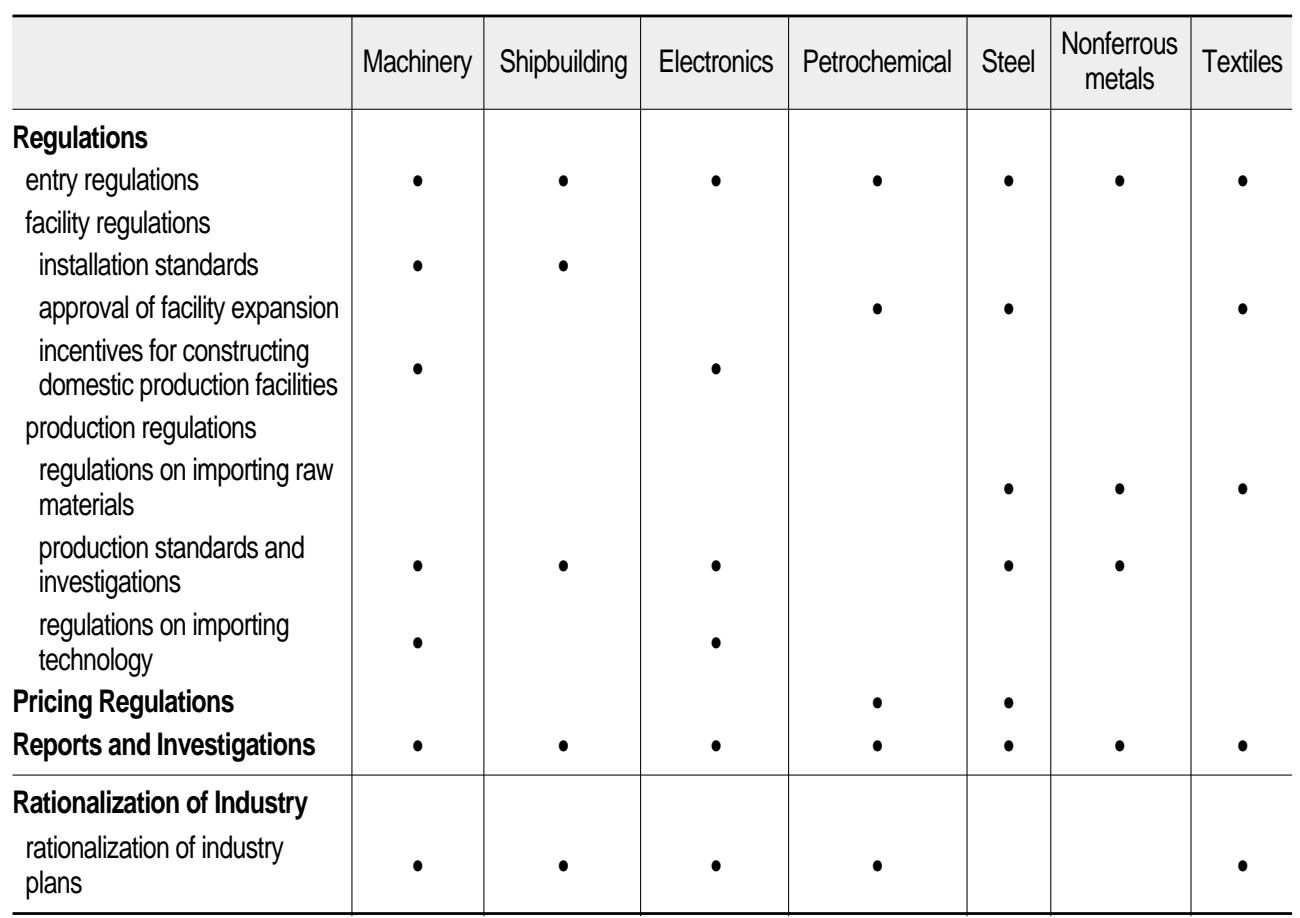




\begin{tabular}{|c|c|c|c|c|c|c|c|}
\hline & Machinery & Shipbuilding & Electronics & Petrochemical & Steel & $\begin{array}{c}\text { Nonferrous } \\
\text { metals }\end{array}$ & Textiles \\
\hline $\begin{array}{l}\text { Research and Development } \\
\text { research and development } \\
\text { assistance } \\
\text { plan for collaboration on } \\
\text { research and development }\end{array}$ & $\bullet$ & & - & $\bullet$ & $\bullet$ & $\bullet$ & \\
\hline $\begin{array}{l}\text { Financial Support } \\
\text { special funds } \\
\text { financial support } \\
\text { assistance } \\
\text { direct assistance } \\
\text { discount on public utility } \\
\text { charges }\end{array}$ & $\begin{array}{l}\bullet \\
\bullet \\
\bullet \\
\bullet\end{array}$ & • & • & & $\bullet$ & $\begin{array}{l}\cdot \\
\bullet \\
\bullet \\
\bullet\end{array}$ & • \\
\hline Special Industrial Estates & - & & - & - & & & $\bullet$ \\
\hline $\begin{array}{l}\text { Administrative Support } \\
\text { support of activities overseas } \\
\text { purchase of raw materials }\end{array}$ & & & $\bullet$ & & $\bullet$ & $\bullet$ & \\
\hline Industry Associations & - & - & - & & & & - \\
\hline
\end{tabular}

Source: B. Lee 1998.

Financial support and funding were usually used as monetary tools. First, President Park offered financial support through the banks, which the military junta had nationalized after the military coup. The government-controlled financial system was completed with the revision of the Bank of Korea Act in 1962. The government sought to effect industrial policies by distributing financial support to export businesses at a low interest rate. Table 8 shows the difference between the standard interest rate and the special interest rate.

Table 8. Difference between the Standard and Special Interest Rates

\begin{tabular}{l|r|r|r|r|r|c}
\hline & 1965 & 1970 & 1975 & 1980 & 1985 & 1990 \\
\hline Return on Corporate Bonds & 14.0 & 24.6 & 20.1 & 30.1 & 14.2 & 16.5 \\
\hline Interest rate on Private Loans & 58.8 & 50.8 & 41.3 & 45.0 & 24.0 & 18.8 \\
\hline Export Financing & 6.5 & 6.0 & 9.0 & 15.0 & 10.0 & 10.0 \\
\hline Facility Fund Rate & 11.0 & 12.0 & 12.0 & 20.0 & 12.0 & 12.0 \\
\hline
\end{tabular}

Source: B. Lee 1998, p. 46. 
Second, the government supported businesses through tax reductions and exemptions. Tax reductions for foreign investors can be seen in table 9. The government also executed fiscal policies of tax reduction and exemption for factories deployed in industrial estates meeting entry regulations.

Table 9. Details of Tax Reduction for Foreign Investors

\begin{tabular}{|c|c|c|}
\hline Type of tax & Tax Rates & Details of Tax Reduction \\
\hline income tax & $8-70 \%$ & $\begin{array}{l}\text { - tax exemption for five years } \\
-50 \% \text { tax reduction for three years after expiration } \\
\text { of initial five-year period of tax exemption }\end{array}$ \\
\hline $\begin{array}{l}\text { tax on earned } \\
\text { income }\end{array}$ & $\begin{array}{l}8-70 \% \\
\text { (foreign income) }\end{array}$ & tax exemption for five years \\
\hline corporate tax & $\begin{array}{l}\text { - publicly held } \\
\text { companies, } 20-27 \% \text {, } \\
25-33 \% \\
\text { - privately held } \\
\text { companies, } 20-40 \%\end{array}$ & $\begin{array}{l}- \text { tax exemption for five years } \\
-50 \% \text { tax reduction for three years after expiration } \\
\text { of initial five-year period of tax exemption }\end{array}$ \\
\hline $\begin{array}{l}\text { special } \\
\text { consumption tax }\end{array}$ & $10-100 \%$ on 20 items & tax exemption on capital goods \\
\hline property tax & $\begin{array}{l}\text { - land, } 0.3-5 \% \\
\text { - houses and ships, } \\
0.3-5 \%\end{array}$ & $\begin{array}{l}\text { - tax exemption for five years } \\
-50 \% \text { tax reduction for three years after expiration } \\
\text { of initial five-year period of tax exemption }\end{array}$ \\
\hline acquisition tax & $\begin{array}{l}\text { - province, city, and } \\
\text { borough, } 10 \% \\
\text { - Seoul and Pusan, } \\
20 \%\end{array}$ & $\begin{array}{l}\text { - tax exemption for five years } \\
-50 \% \text { tax reduction for three years after expiration } \\
\text { of initial five-year period of tax exemption }\end{array}$ \\
\hline
\end{tabular}

Source: D. Choi 1991, p. 114.

Policies were also made to strengthen exports and to regulate imports by connecting them with the exchange rate policy. The exchange rate depreciated almost $100 \%$ per year from 1961 to 1964 . The foreign exchange deposit system was replaced with the foreign exchange concentration system, which required exporters to deposit their income in dollars in the central bank, in 1961. In addition, an incentive system was formed for exports; the export and import link system was imposed in 1963, which assigned import entitlement to exporters (H. Jang, 1999).

The government devised nonmonetary incentives as well. A representative example was the establishment of the export day, which acknowledged the most successful businesses as well as those of merit. In particular, the business that was rewarded was promoted in the mass media and received tax reductions as well as an audit exemption. 
The recipient of the reward was not limited to representatives from export businesses either, as engineers were eligible if they contributed to improving the productivity of exports by developing a new method of production or a new exported good (Kang et al., 2008, pp. 206-209).

In addition to incentives, regulations used to monitor and assign responsibilities were also designed. For example, the role of the 'export responsibility system' was important in increasing exports in the early days of Korea's economic development (C. Park, 1958). The export responsibility system was managed by assigning export responsibilities for an established total amount to exporters through export plans.

However, since 1963, there has been an administrative order requiring exporters to report what they plan to export every month and what they in fact end up exporting each month. Anyone who failed to submit this report was excluded from the support system for export promotion and penalized. As seen in figure 3 , although the quantity of exports seems as though it was determined by reports from private traders and the government's export enhancement plan, in fact at this time exporters had to export the number of items the government specified (Kang et al., 2008, pp. 166-167). Nevertheless, the government had to resolve the difficulties exporters confronted when they failed to meet the target (Ha, 2006, p. 197), and business leaders' needs were satisfied during the process. Thus, the export target policy provided a means for sharing goals, results, and responsibilities between the government and businesses, outside of regulations.

Figure 3. Setting Export Target Figures

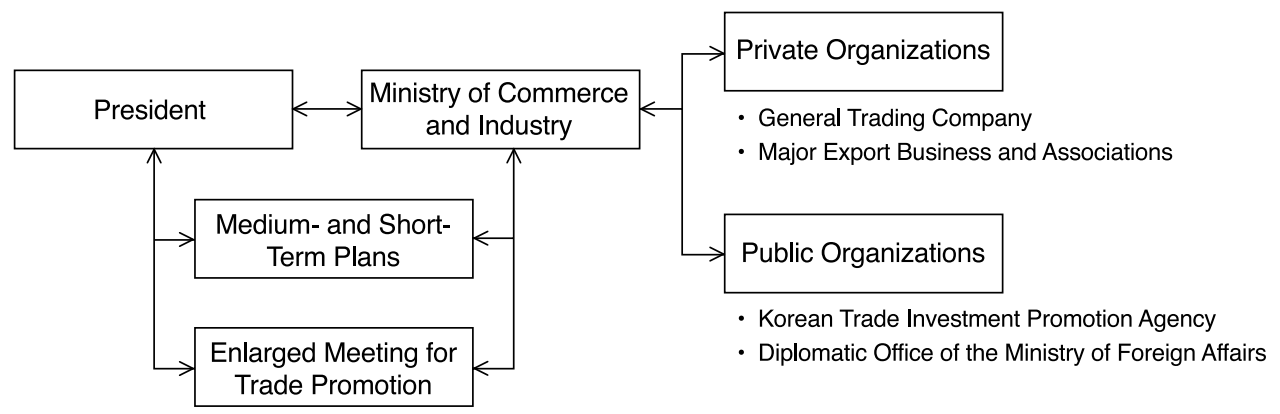

Source: Adapted from D. Choi 1991, p. 111.

\section{Roles of Actors}

President Park authorized the implementation of decisions regarding industrial policy. Especially in the 1970s, he encouraged exporters, even using the term, "export war." And various organizations were established to ensure communication, coopera- 
tion, and the sharing of information between the government and business enterprises, such as industrial associations. The government required all enterprises to join the industrial associations, which were founded either on the initiative of the industry itself or with the encouragement of the government (Fields, 1997, p. 135). Some of the associations predated the coup, such as the Korea Chamber of Commerce and Industry, the Korean Trade Association, and the Spinning and Weaving Association of Korea. From the end of the 1960s through the 1970s, new industrial associations representing each field were founded, including the Korea Association of Machinery Industry, as the government focused on the strategic industries. These associations were used by the government as a means to effectively control and guide a particular field or company (Hart-Lansberg, 1993, p. 51). And the associations contributed to ensuring the flow of information between the government and the enterprises and helped coordinate the activities of the enterprises through the official council, acting as an intermediary between the MCI and individual businesses (Root, 1996, p. 26).

There were also frontline organizations that led exports, standing in for the government in the field, such as the Korea Trade Investment Promotion Agency, which the government founded in 1962. The agency conducted foreign market research and helped enterprises to find trade deals. The government also came to see itself as a "general trading company" that had played a critical role in transforming Japan into a powerful export nation. Thus, the government institutionalized the general trading companies (Y. Park, 2008), which acted as frontline organizations of "Korea, Inc." Moreover, the government supported enterprises by establishing public enterprises to build and manage industry infrastructures.

\section{Feedback}

One of the primary characteristics of industrial policies in Korea was the active feedback provided by both government-run organizations and the business enterprises. ${ }^{4}$ As main enactors of the industrial policy, the enterprises presented summaries of market information and problems to the government. The executive branches of the governmentrun organizations circulated information regarding problems and the outlined possible solutions. The government-run banks, the public institutes, and the Korea Trade Investment Promotion Agency circulated both market information and new ideas. This feedback was typically provided in forums such as the economic issues briefing meeting and the enlarged meeting for trade promotion.

4. This section is mostly based on S. Kim 2000. 


\section{Institutions}

The economic issues briefing meeting and the enlarged meeting for trade promotion were introduced around the same time, in 1964 and 1965, which was when economic growth kicked into high gear, and at these meetings, participants regularly evaluated and examined the economic situation and export status (Kang et al., 2008, p. 252). The following excerpt from the minutes of a 1968 enlarged meeting for trade promotion suggests that analyses of the performance record and difficulties exporters faced were carried out, that solutions were sought, and that reports on the results of export activity were reported.

"At the sixth enlarged meeting for trade promotion, on July 1, the participants analyzed export performance up to the end of May and discussed how to promote exports. ... Meanwhile, the president ordered the promotion of foreign currency savings and policies on sound consumption on a continual basis, so as to avoid a radical import inhibition with a consideration of the impact on prices. Giving a brief outline of the results of suggestions at the fifth meeting, participants reported that they have eased the exclusive export right system as a way of overcoming sluggish exports to Sweden. . . . For the rest, they analyzed export performance over the past month, classified by main items exported, the regions they were exported from, and their industry (S. Jang, 2006, p. 166).”

Institutions were also aligned so that businessmen could advance the suggestions in the economic issues briefing meeting and the enlarged meeting for trade promotion. For example, the emergency order regarding economic growth and stabilization was an action suggested by businessmen. The Federation of Korean Industries officially suggested an interest rate cut in January 1972, and two businessmen who were invited to the enlarged meeting for trade promotion proposed in person that the rate should be lowered. In response to this, the loan freeze was launched as an emergency act in August (Kang et al., 2008, pp. 126-131).

Active feedback was likewise provided during the intermediate level of meetings between the government and the enterprises. The meetings were in the form of a round table and council, and they were either comprehensive or partial. The comprehensive meetings were working-level export promotion meetings, with the assistant secretary of the MCI serving as the chairman. The partial meetings were working-level departmental meetings, classified according to six aspects: planning, agriculture and forestry, marine industry, mining industry, and light and heavy industry (Korea Trade Investment Promotion Agency, 1992, p. 68).

In addition, before and after the enlarged meeting for trade promotion, regular 
export promotion meetings, regional export meetings, and other departmental meetings to discuss particular export items were held. The regular export promotion meeting built close cooperation systems between the government and the enterprises. The departmental meetings were held frequently to analyze the reasons for weak export items and develop countermeasures. The regional export promotion meetings were held when the regular export promotion meetings required them. These meetings fostered cooperation between the government and the enterprises by making recommendations to the government after considering problems and difficulties and by sharing the results of the enlarged meeting for trade promotion (Korea Trade Investment Promotion Agency, 1992, pp. 171, 153).

\section{Roles of Actors}

The government and the businessmen exchanged information through the various institutions we have described aformentioned. For businessmen, these institutions provided opportunities for solving problems, and for the government, they were channels for gathering information and managing export goals (Fields, 1997, p. 139). The MCI gathered information from the individual export companies on a weekly and monthly basis and monitored and analyzed changes in market conditions. Using the feedback process, the government updated export items and policies as needed, enabling both itself and the enterprises to react quickly to a rapidly changing world market (Camposs \& Root, 1996, p. 90).

The CEO of Hyundai, Joo-young Jung, who served as the chairman of the Federation of Korean Industries, mentioned that the government tended to consult with large companies before making final decision on economic policies (Sisa Journal, May 7, 1992). Indeed, $70 \%$ of the economic policies recommended by Federation of Korean Industries were adopted by the government (Bae, 1983, p. 294). Bureaucrats and the businessmen also maintained an unofficial channel that allowed feedback. They worked together, forming unofficial consultative groups and exchanging information through irregular and unofficial meetings in private places. 5

5. The following testimonies from former officials of MCI depict how information pertaining to industrial policy was exchanged through irregular and unofficial meetings of public officials and businessmen in private places. Mr. C., a former official of MCI stated, "I was not able to make a yearly supply and demand program. So, a public corporation had sent an employee, and we worked together all night, in the inn. ... I could not have completed the task without him." Mr. O., a former official of MCI commented that "the businessmen 


\section{CONCLUSION}

According to the results of our analysis, the governance system of industrial policy in Korea during the era of its economic growth is closest to the étatiste model. The Korean state was a principal actor that exerted state power as a means of promoting industry and economic development. In each stage of the governance process, the government established effective and efficient state institutions that not only enhanced the industrial policy capacity of the government but also created an environment that permitted various stakeholders in business and related academia and research were able to participate.

President Park's strong determination and his commitment to industrial promotion compelled high-level government officials undertake significant steps in support of industrial policy. Bureaucrats and businessmen maintained formal and informal channels that allowed information and knowledge related to industrial policy to circulate, and this circulation of information and knowledge was reflected in industrial policy programs. Various kinds of private actors, including professors, researchers in think tanks, businessmen, and staffs of industrial associations, were mobilized and participated in the governance process.

These governance mechanisms produced good outcomes in terms of cohesiveness, adaptability, and accountability, at least with respect to the outcomes of industrial policy. Cohesiveness was high owing to the bonding among the various actors of multilevel institutions who participated in elaborating industrial policy and were given opportunities to strengthen the link between actors and organizations and programs at each stage in the process. Adaptability was enhanced. Policy decisions could be quickly made under such kinds of institutional arrangements. Moreover, quick feedback from the market and businesses contributed to facilitating the operation of error correction systems. That is to say, quick feedback made it possible to fix small errors and policy weaknesses before a large-scale policy failure occurred. Accountability was also enhanced in this system. The meetings presided over by the president made high-ranking officials more accountable to policy results and more sensitive to their performance.

However, this étatiste model of governance system for industrial policy worked at the expense of democratization (Pierre \& Peters, 2005, p. 17). For example, under the 1972 Yushin Constitution, human rights and political freedoms were subject to restriction in the name of economic development and national security. The dominance of state in the field of industrial policy invited the abuse of government power, corruption

came to my office with information. But that was not enough. So, people like us used to meet at coffee shops before going to work in the morning" (Ha, 2006, 143-144). 
of public officials, and favoritism in industrial policy. The state exerted its power to put firms and companies out of business by shutting off their access to credit unless they followed the government's policy. There were rampant suspicions and rumors about inappropriate relationships between big businesses (chabols) and the political leadership. In turn, these suspicion and rumors led to debates over the injustice and unfairness of Korean society and the political and social costs of rapid industrial growth. This governance system was also problematic in terms of inclusiveness because the representatives in the fields of labor and agriculture were not allowed to participate in the process of governance (Jung, 2014, pp. 206-207; Ko, 2008; J. Choi, 2002).

What are the theoretical and practical implications of the results of this study? First, it should be emphasized that the state and society worked together in formulating and implementing industrial policy. Businessmen and experts from private economic organizations who participated in industrial policy making, in turn, became one of the major sources of information for public agencies and the driving forces behind industrial promotion, helping to strengthen public institutions for industrial policy. Second, the importance of institutional innovations for industrial promotion, such as the five-year plan system for economic development, pan-governmental meetings presided over by the president, both incentive-based and non-incentive-based industrial policy instruments, and 'winner-picking systems' that promoted competition between the businesses, should be stressed. These innovations not only were instrumental in stimulating changes but also complemented the weakness of the étatiste model of industrial policy governance in Korea.

\section{REFERENCES}

Bae, B. 1983. The secret story of the Korean business community. Seoul: Donggwang Press.

Bae, K., \& S. Eom. 2012. Korean state apparatuses from 1948 to 1972: Continuity and discontinuity. Korean Public Administration Review, 46(3): 329-356.

Bell, S., \& A. Hindmoor. 2009. Rethinking governance: The centrality of the state in modern society. Cambridge: Cambridge University Press.

Camposs, J. E., \& H. L. Root. 1996. The key to the Asian miracle. Washington, DC: Brookings Institution.

Choi, D. 1991. Government in the era of growth. Seoul: Korea Economy Newspaper Co.

Choi, J. 2002. Democracy after democratization. Seoul: Humanitas. 
Choi, S. 2008. The growth of big business and the relations between government and big business in historical perspective. History Review, 84(autumn): 100-128.

Choi, S. 2010a. Export-oriented industrialization policy in Korea: An analysis of causes of rapid growth in exports in the early 1960s. Review of Business History, 25(3): 197-224.

Choi, S. 2010b. Export-oriented industrialization and the government's role in Korea, 1965-1979: The case of the enlarged meeting for export promotion. Review of Business History, 25(4): 355-383.

Cole, D., \& Y. Nam. 1969. The pattern and significance of economic planning in Korea. In I. Adelman (ed.), Practical approaches to development planning: Korea's second five-year plan (pp.11-38). Baltimore : Johns Hopkins Press.

Economy Planning Board. 1962. Economic development plan 1. Seoul: Republic of Korea.

Economy Planning Board. 1966. Economic development plan 2. Seoul: Republic of Korea.

Economy Planning Board. 1971. Economic development plan 3. Seoul: Republic of Korea.

Economy Planning Board. 1976. Economic development plan 4. Seoul: Republic of Korea.

Economic Reconstruction Planning Committee. 1962. Explanation of joint economy reconstruction plan 4295-4299. Seoul: Republic of Korea.

Evans, P. 1995. Introduction: Development strategies across the public-private divide. In P. Evans (ed.), State-society synergy: Government and social capital in development (pp.1-10). Berkeley: University of California.

Fields, K. 1997. Strong states and business organization in Korea and Taiwan. In S. Maxfield \& B. R. Schneider (eds)., Business and the state in developing countries (pp. 36-60). Ithaca, NY: Cornell University Press.

Hart-Lansberg, M. 1993. The rush to development: Economic change and political struggle in South Korea. New York: Monthly Review Press.

Ha, Y. 2006. Late industrialization and the dynamics of the strong state in South Korea: Debureaucratization and hollowing out. Seoul: Seoul National University Press.

Hwang, B. 2011. An Economy Planning Board section chief's view of Park Chung Hee. Seoul: Chosun News Press.

Jang, H. 1999. Korean development strategy in the 1960s and the formation of industrial policy. In Academy of Korean Studies (ed.), Industrialization and the economic structure of Korea in the 1960s (pp.77-126). Seoul: Baeksanseodang.

Jang, S. 2006. A study of the primary causes of increase in exports in the era of rapid 
growth in Korea, with an emphasis on the export promotion conference with enlarged membership and transaction costs. $\mathrm{PhD}$ diss., Chungang University.

Jung, J. A. 2007. An analysis of the economic policy of the Rhee Syng Man administration in the first republic. $\mathrm{PhD}$ diss., Yonsei University.

Jung, J. G. 1994. President's and economic leadership: The management of economic policy during the Park Chung Hee, Chun Doo Hwan, and Rho Tae Woo administrations. Seoul: Korea Economy Newspaper Company.

Jung, Y. 1983. Regulatory Policy in Korea : Presidential Emergency Decree for Economic Stability and Growth of August 3, 1973. Korean Public Administration Review, 17(1): 89-117.

Jung, Y. 2014. The Korean state, public administration, and development: Past, present, and future challenges. Seoul: SNU Press.

Kang, G, Y. Lee, \& S. Choi. 2008. Policy-making systems in the era of rapid growth in Korea. Seoul: Korean Development Institute Press.

Kim, H. 2009. Network analysis of the industrial policy of the Park Chung Hee administration: Analysis of the interview data (1964-1979) of former president Park Chung Hee. PhD diss., Hansung University.

Kim, J. 2004. Capital accumulation and the rise of the state in South Korea, 1950s1960s. Trend and Prospect, 60: 197-241.

Kim, S. 2010. Government, business, and economic growth: Government-business relations in Korea. Korean Public Administration Review, 34(1):41-58.

Kim, Y. et al. 2010. (Science president) Park Chung-hee and his leadership. Seoul: MSD Media.

Ko, Y. 2008. Economic development and the role of government in Korea: Past, present and future. Seoul: Korean Development Institute Press.

Korea Trade Investment Promotion Agency. 1992. Thirty years of export promotion in Korea. Seoul: Korea Trade Investment Promotion Agency.

Kwon, H. 2010. Implications of Korea's saemaul undong for international development policy: A Structural Perspective. Korean Journal of Policy Studies, 25(3): 87-100.

Lee, B. 1998. The source of economic growth and the role of industrial policy in Korea. Seoul: Kia Economics Research Institute.

Lee, S. 1995. Mr. President, let us revolutionize. Seoul: Seojeokpo.

Lee, Y. 2012. Change of economic developmental strategy in the early 1960's in Korea and its economic history. Korean Economic Journal, 51(1): 107-123.

Lynn, L., C. Heinrich, \& C. Hill. 2001. Improving governance: A new logic for empirical research. Washington, DC: Georgetown University Press.

Oh, W. 1995. Constructing the Korean economy: An engineering model. Vol. 1. Seoul: Kia Economics Research Institute. 
Oh, W. 1996. Constructing the Korean economy: An engineering model. Vol. 3. Seoul: Kia Economics Research Institute.

Oh, W. 2006. How Park Chung Hee made Korea an economic power. Seoul: Dongsuh Press.

Park, C. 1962. Text of a speech delivered January 1, 1962. Speeches to Korean Citizens. Seoul: Dongsuh Press, 2006.

Park, Y. 2008. Process and character of the four core plants plan, 1969. Economic History, 44: 81-107.

Pierre, J., and B. Peters. 2005. Governing complex societies: Trajectories and scenarios. New York: Palgrave Macmillan.

Rhodes, A. 1996. The new governance: Governance without government. Political Studies, 44(3): 652-667.

Root, H. 1996. Small countries, big lessons: Governance and the rise of East Asia. Oxford: Oxford University Press.

Sagong, I., \& L. Jones. (1981). Government, business, and entrepreneurship in economic development: The Korean Case. Seoul: Korean Development Institute Press.

Stoker, G. 1998. Governance as theory: Five propositions. International Social Science Journal, 50(155): 17-28.

Timmermans, A. 2001. Arenas as institutional sites for policymaking: Patterns and effects in comparative perspective. Journal of Comparative Policy Analysis, 3(3): 311-337.

UNESCAP [United Nations Economic and Social Commission for Asia and the Pacific]. 2007. What is good governance? Bangok: UNESCAP.

Weaver, K., \& B. A. Rockman. 1993. Assessing the effect of institutions. In K. Weaver \& B. A. Rockman (eds.), Do Institutions Matter? (pp.1-41). Washington DC: Brookings Institute.

Westphal, L. 1990. Industrial policy in an export-propelled economy: Lessons from South Korea's experience. Journal of Economic Perspectives, 4(3): 41-59.

World Bank. 1992. Governance and development. Washington, DC: World Bank. 